Article

\title{
Chemical Characterization and Trypanocidal, Leishmanicidal and Cytotoxicity Potential of Lantana camara L. (Verbenaceae) Essential Oil
}

\author{
Luiz Marivando Barros ${ }^{1,2}$, Antonia Eliene Duarte ${ }^{1,2}$, Maria Flaviana Bezerra Morais-Braga ${ }^{1}$, \\ Emily Pansera Waczuk ${ }^{2}$, Celeste Vega ${ }^{1}$, Nadghia Figueiredo Leite ${ }^{1}$, \\ Irwin Rose Alencar de Menezes ${ }^{3}$, Henrique Douglas Melo Coutinho ${ }^{1}$, \\ João Batista Teixeira Rocha ${ }^{2}$ and Jean Paul Kamdem ${ }^{2,4, *}$ \\ 1 Laboratório de Microbiologia e Biologia Molecular, Universidade Regional do Cariri, \\ Crato-CE CEP 63105-000, Brazil; lmarivando@hotmail.com (L.M.B.); duarte105@yahoo.com.br (A.E.D.); \\ flavianamoraisb@yahoo.com.br (M.F.B.M.-B.); mcvegagomez@gmail.com (C.V.); \\ nadghia.fl@gmail.com (N.F.L.); hdmcoutinho@gmail.com (H.D.M.C.) \\ 2 Post-Graduate Program in Biological Sciences, Biochemical Toxicology, Federal University of Santa Maria, \\ Santa Maria-RS CEP 97105-900, Brazil; memypw@yahoo.com.br (E.P.W.); jbtrocha@yahoo.com.br (J.B.T.R.) \\ 3 Program of Post-Graduation in Molecular Bioprospection, Laboratory of Pharmacology and \\ Molecular Chemistry, Chemistry Biology Department, Regional University of Cariri, Crato, CEP 63105-000, \\ Brazil; irwin.alencar@urca.br \\ 4 Departamenro de Bioquímica, Instituto de Ciências Básica da Saúde, Universidade Federal do Rio Grande \\ do Sul, Porto Alegre-RS CEP 90035-003, Brazil \\ * Correspondence: kamdemjeanpaul2005@yahoo.fr or jpkamdem@gmail.com; Tel.: +55-55-3220-9462
}

Academic Editor: Marcello Iriti

Received: 20 December 2015; Accepted: 2 February 2016; Published: 10 February 2016

\begin{abstract}
Drug resistance in the treatment of neglected parasitic diseases, such as leishmaniasis and trypanosomiasis, has led to the search and development of alternative drugs from plant origins. In this context, the essential oil extracted by hydro-distillation from Lantana camara leaves was tested against Leishmania braziliensis and Trypanosoma cruzi. The results demonstrated that L. camara essential oil inhibited T. cruzi and L. braziliensis with $\mathrm{IC}_{50}$ of $201.94 \mu \mathrm{g} / \mathrm{mL}$ and $72.31 \mu \mathrm{g} / \mathrm{mL}$, respectively. L. camara essential oil was found to be toxic to NCTC929 fibroblasts at $500 \mu \mathrm{g} / \mathrm{mL}\left(\mathrm{IC}_{50}=301.42 \mu \mathrm{g} / \mathrm{mL}\right)$. The composition of L. camara essential oil analyzed by gas chromatography-mass spectrometry (GC/MS) revealed large amounts of $(E)$-caryophyllene $(23.75 \%)$, biciclogermacrene $(15.80 \%)$, germacrene $\mathrm{D}(11.73 \%)$, terpinolene $(6.1 \%)$, and sabinene $(5.92 \%)$, which might be, at least in part, responsible for its activity. Taken together, our results suggest that L. camara essential oil may be an important source of therapeutic agents for the development of alternative drugs against parasitic diseases.
\end{abstract}

Keywords: Lantana camara; Leishmania braziliensis; Trypanosoma cruzi; essential oil

\section{Introduction}

Leishmaniasis is a complex disease known to cause serious public health problems in 88 countries (mainly from Africa, Asia, and Latin America) where the disease was found to be endemic [1]. It is caused by protozoan parasites from more than 21 Leishmania species that are transmitted to humans by bites of about 30 species of infected female phlebotomine sandflies [2-4].

The complexity of leishmaniasis is probably attributed to its multiple forms, including cutaneous, visceral, and mucocutaneous, which result from the replication of the parasite in macrophages in the mononuclear phagocyte system, dermis, and naso-oropharyngeal mucosa, respectively $[5,6]$. 
According to the World Health Organization [1], 12 million of people are affected by the disease and the number of new cutaneous and visceral leishmaniases cases reported are increasing annually. In Brazil, for instance, ten among the fourteen species identified of Leishmania have been reported to infect human [7] and about 26,000 new cases of the disease are registered per year [8,9]. This is, at least in part, because the currently-available drugs (e.g., Pentavalent antimony, Paramomycin sulfate) (i) are unaffordable for the developing countries, and (ii) have developed resistance to parasites [6,10-12].

Another protozoan disease that is of critical concern in the Latin America is Chagas disease, which is caused by Trypanosoma cruzi. Its transmission to human is through feces of infected triatomine insects $[13,14]$. Like leishmaniasis, the available drugs for the treatment of Chagas disease (nifurtimox and benznidazole) are associated with undesirable effects and are not effective against the chronic forms of the disease $[15,16]$.

Since the last decade, there has been a growing interest from the scientific community for the use of natural therapeutic agents in combating parasitic protozoa diseases including leishmaniasis and trypanosomiasis [17-19]. This is because natural therapeutic agents are generally regarded as safe, affordable, and are found to be more effective than synthetic pharmaceuticals in chronic diseases $[18,19]$.

Lantana camara, commonly known in Brazil as "camara" and "camara de espinho", is one of the most toxic plants with diverse and broad geographic distribution [20-24]. Its toxicity has been reported in animals [25]. The plant extracts of L. camara are used in folk medicine for the treatment of catarrhal infections, cancers, ulcers, asthma, high blood pressure, swellings, tetanus, malaria, chicken pox, bronchitis, respiratory diseases, and rheumatism [21,26,27]. Of pharmacological therapeutic importance, $L$. camara methanolic extract was reported to exhibit anti-leishmanial activity against the promastigote forms of Leishmania amazonensis [27]. On the other hand, L. camara oil is used for the treatment of skin itches, as an antiseptic for wounds, and externally for leprosy and scabies [22]. In addition, substantial evidence from the literature indicates that essential oil from the leaves of L. camara exhibit anti-inflammatory, antibacterial, antifungal, and antimicrobial activities [28-31].

Although the use of essential oils from plant extracts for the treatment of parasitic protozoa diseases is less investigated, they can be of utmost importance for the development of new drugs against parasitic diseases. Their low density associated with their rapid diffusion across cell membranes (as a result of their liposolubility) can enhance the integration of their active components into the parasites. In this context, the present study aimed to investigate, the trypanocidal, leishmanicidal, and cytotoxic potential of essential oil from the leaves of L. camara. Further, chemical characterization of L. camara leaf essential oil was performed using gas chromatography-mass spectrometry (GC/MS).

\section{Results}

\subsection{GC/MS Analysis of L. camara Leaf Essential Oil}

Table 1 shows the chemical composition of L. camara essential oil analyzed by GC-MS. As it can be seen, twenty seven (27) different compounds representing $98.69 \%$ of the total oil were identified. Based on our results, it appears that the major constituents were: $(E)$-caryophyllene $(23.75 \%)$, bicyclogermacrene $(15.80 \%)$, germacrene D $(11.73 \%)$, terpinolene $(6.01 \%)$, and sabinene $(5.92 \%)$, while camphene $(0.07 \%), \alpha$-terpinene $(0.08 \%)$, $t$-sabinene-hydrate $(0.13 \%), \alpha$-pinene $(0.19 \%)$, and terpin-4-ol $(0.25 \%)$ were the less abundant chemicals found in L. camara essential oil (Table 1$)$. 
Table 1. Composition of Lantana camara leaf essential oil.

\begin{tabular}{|c|c|c|c|}
\hline Compounds & $\mathbf{R I}^{\mathbf{a}}$ & $\mathbf{R I}^{\mathbf{b}}$ & Oil Composition (\%) \\
\hline$\alpha$-Pinene & 939 & 937 & 0.19 \\
\hline Camphene & 953 & 951 & 0.07 \\
\hline Sabinene & 976 & 675 & 5.92 \\
\hline$\beta$-Pinene & 980 & 983 & 0.45 \\
\hline Myrcene & 991 & 990 & 0.31 \\
\hline$\alpha$-Terpinene & 1018 & 1015 & 0.08 \\
\hline$p$-Cymene & 1026 & 1026 & 2.73 \\
\hline (Z)- $\beta$-Ocimene & 1040 & 1037 & 0.68 \\
\hline (E)- $\beta$-Ocimene & 1050 & 1054 & 0.93 \\
\hline$\gamma$-Terpinene & 1062 & 1061 & 1.84 \\
\hline Terpinolene & 1088 & 1079 & 6.01 \\
\hline Terpin-4-ol & 1177 & 1174 & 0.25 \\
\hline$\alpha$-Terpineol & 1189 & 1193 & 1.02 \\
\hline$t$-Sabinene hydrate & 1254 & 1257 & 0.13 \\
\hline$\alpha$-Copaene & 1376 & 1376 & 0.93 \\
\hline$\beta$-Elemene & 1391 & 1389 & 1.50 \\
\hline$\beta$-Caryophyllene & 1404 & 1401 & 3.46 \\
\hline (E)-Caryophyllene & 1418 & 1423 & 23.75 \\
\hline Aromandendrene-allo & 1461 & 1460 & 2.17 \\
\hline$\alpha$-Humulene & 1454 & 1451 & 4.04 \\
\hline Germacrene D & 1480 & 1480 & 11.73 \\
\hline Valencene & 1491 & 1489 & 8.32 \\
\hline Bicyclogermacrene & 1494 & 1497 & 15.80 \\
\hline Cubebol & 1514 & 1518 & 1.47 \\
\hline$\delta$-Cadinene & 1513 & 1509 & 0.26 \\
\hline Spathulenol & 1576 & 1573 & 1.98 \\
\hline Caryophyllene oxide & 1581 & 1585 & 2.67 \\
\hline Total identified (\%) & - & - & 98.69 \\
\hline
\end{tabular}

Relative proportions of the essential oil constituents were expressed as percentage. ${ }^{\text {a }}$ Retention indices from literature [32]; ${ }^{\mathrm{b}}$ Retention indices experimental (based on homologous series of $n$-alkane $\mathrm{C}_{7}-\mathrm{C}_{30}$ ).

\subsection{Effect of L. camara Leaf Essential Oil against T. cruzi}

L. camara essential oil inhibited T. cruzi growth as depicted in Table 2. At the highest concentration tested $(250 \mu \mathrm{g} / \mathrm{mL})$, L. camara essential oil reduced the number of the parasites by almost $70 \%$, when compared to control group. Nifurtimox $(50 \mu \mathrm{g} / \mathrm{mL})$, which was used as standard drug against the epimastigotes of $T$. cruzi, killed about $93 \%$ of $T$. cruzi. The $\mathrm{IC}_{50}$ values (concentration required to kill or inhibit the growth of parasites by 50\%) for epimastigotes of T. cruzi were 3.02 and $201.94 \mu \mathrm{g} / \mathrm{mL}$ for nifurtimox and L. camara essential oil, respectively.

Table 2. Activity of essential oil from leaves of L. camara against T. cruzi.

\begin{tabular}{cccc}
\hline Nifurtimox $(\mu \mathrm{g} / \mathrm{mL})$ & \%AE & Essential Oil $(\mu \mathrm{g} / \mathrm{mL})$ & \%AE \\
\hline- & - & 250 & $67.39 \pm 0.26$ \\
- & - & 125 & $22.04 \pm 5.89$ \\
100 & $100 \pm 0.46$ & - & - \\
- & - & 62.5 & $0 \pm 3.06$ \\
50 & $93 \pm 0.66$ & - & - \\
10 & $84 \pm 0.62$ & - & - \\
1 & $43 \pm 0.93$ & - & - \\
0.5 & $13 \pm 2.50$ & - & - \\
0.1 & $0 \pm 1.54$ & & $201.94 \pm 1.2$ \\
\hline $\mathrm{IC}_{50}(\mu \mathrm{g} / \mathrm{mL})$ & $3.02 \pm 0.75$ &
\end{tabular}

\%AE: percentage of epimastigotes of T. cruzi killed after treatment with nifurtimox or L. camara essential oil. Results are the mean of $n=3$ independents experiments performed in triplicate. 


\subsection{Effect of Essential Oil from L. camara Leaves against Leishmania braziliensis}

Essential oil from the L. camara leaves killed the promastigotes of Leishmania braziliensis in a concentration-dependent manner (Table 3). Of particular therapeutic importance, $100 \mu \mathrm{g} / \mathrm{mL}$ of L. camara essential oil killed $100 \%$ of the L. braziliensis promastigote forms of the parasite, while the standard drug used (pentamidine) killed $94 \%$ of the promastigotes. However, pentamidine was more effective than L. camara essential oil, since the concentration needed to kill $50 \%\left(\mathrm{IC}_{50}\right)$ of the parasites was 5.69 , whereas the $\mathrm{IC}_{50}$ for the essential oil of $L$. camara was $72.31 \mu \mathrm{g} / \mathrm{mL}$.

Table 3. Activity of L. camara leaf essential oil against Leishmania braziliensis.

\begin{tabular}{cccc}
\hline Pentamidine $(\mu \mathrm{g} / \mathrm{mL})$ & \%AP & Essential Oil $(\mu \mathrm{g} / \mathrm{mL})$ & \%AE \\
\hline- & - & 250 & $100 \pm 0.76$ \\
- & - & 125 & $100 \pm 1.25$ \\
- & - & 100 & $100 \pm 2.23$ \\
100 & $93.9 \pm 0.3$ & - & - \\
- & - & 80 & $94.95 \pm 1.46$ \\
- & - & 70 & $36.4 \pm 2.22$ \\
- & - & 62.5 & $16.44 \pm 0.90$ \\
- & - & 50 & $15.9 \pm 1.50$ \\
50 & $93.9 \pm 0.1$ & - & - \\
25 & $89.2 \pm 0.6$ & - & - \\
12.5 & $80.6 \pm 0.2$ & - & - \\
6.25 & $54.2 \pm 0.3$ & - & - \\
3.125 & $15.5 \pm 1.1$ & - & $72.31 \pm 0.89$ \\
$\mathrm{IC}_{50}(\mu \mathrm{g} / \mathrm{mL})$ & $5.69 \pm 0.42$ & &
\end{tabular}

\%AP: percentage of promastigotes of L. braziliensis killed by pentamidine or essential oil of L. camara.; $\%$ AE: percentage of epimastigotes of $T$. cruzi killed after treatment with pentamidine or L. camara essential oil. Results are the mean of $n=3$ independents experiments performed in triplicate.

\subsection{Effect of L. camara Leaf Essential Oil on NCTC929 Fibroblasts}

The cytotoxic potential of essential oil from L. camara in NCTC929 fibroblasts is shown in Table 4. Essential oil of L. camara at a concentration of $500 \mu \mathrm{g} / \mathrm{mL}$ completely killed the fibroblasts, while the same effect was observed for nifurtimox (the reference drug) at concentrations ranging from 200 to $600 \mu \mathrm{g} / \mathrm{mL}$. The order of effectiveness of killing the fibroblast was: nifurtimox $\left(\mathrm{IC}_{50}=82.39 \mu \mathrm{g} / \mathrm{mL}\right)>$ L. camara essential oil $\left(\mathrm{IC}_{50}=301.42 \mu \mathrm{g} / \mathrm{mL}\right)$ (Table 4$)$.

Table 4. Toxicity of Effect of L. camara leaf essential oil on NCTC929 fibroblast.

\begin{tabular}{cccc}
\hline Nifurtimox $(\mu \mathrm{g} / \mathrm{mL})$ & $\% \mathrm{C}$ & Essential Oil $(\mu \mathrm{g} / \mathrm{mL})$ & $\% \mathbf{C}$ \\
\hline 600 & $100 \pm 4.4$ & - & - \\
- & - & 500 & $100 \pm 1.49$ \\
400 & $100 \pm 3.8$ & - & - \\
- & - & 250 & $14.57 \pm 0.72$ \\
200 & $100 \pm 0.7$ & - & - \\
- & - & 125 & $7.28 \pm 1.18$ \\
100 & $64 \pm 1.7$ & - & - \\
- & - & 62.5 & $6.06 \pm 7.72$ \\
50 & $7.0 \pm 2.3$ & - & - \\
- & - & 31.25 & $0.0 \pm 4.09$ \\
25 & $1.4 \pm 1.4$ & - & - \\
$\mathrm{IC}_{50}(\mu \mathrm{g} / \mathrm{mL})$ & $82.39 \pm 2.16$ & & $301.42 \pm 3.1$ \\
\hline
\end{tabular}

\%C: percentage of NCTC929 fibroblasts killed by nifurtimox or essential oil of L. camara. Results are the mean of $n=3$ independents experiments performed in triplicate. 


\section{Discussion}

There are an increased interest in finding alternative drugs from the plant kingdom for the treatment of neglected parasitic diseases, in an attempt to replace or supplement those in current use [17,18,33]. Nowadays, phytochemicals are being synthesized and chemically modified to warrant higher potency against these human pathogens [18]. As a pre-requisite for the identification and isolation of active component(s) from plant extracts and/or essential oils, the knowledge of their biological activity is required. In this context, the main objective of the present study was to investigate the biological activities of L. camara essential oil with emphasis to its potential to inhibit the promastigote and epimastigote forms of Leishmania braziliensis and Trypanosoma cruzi, respectively.

Previous studies have reported the leishmanicidal activity of L. camara leaf essential oil on promastigote forms of L. chagasi and L. amazonensis [34] as well as its antibacterial activity [31]. Here, the anti-leishmanicidal activity of L. camara essential oil was assessed against the promastigote form of Leishmania braziliensis. Comparing our results with that obtained by Machado et al. [34], it is possible to extrapolate that L. camara essential oil was more effective against L. amazonensis $\left(\mathrm{IC}_{50}=0.25 \mu \mathrm{g} / \mathrm{mL}\right)$ and L. chagasi $\left(\mathrm{IC}_{50}=18 \mu \mathrm{g} / \mathrm{mL}\right)$ than L. braziliensis $\left(\mathrm{IC}_{50}=72.31 \mu \mathrm{g} / \mathrm{mL}\right) \mathrm{used}$ in this study. Similar observation was reached by Morais-Teixeira et al. [35] when using meglumine antimoniate against the three species of Leishmania. In a region of Tunisia (Sned region) endemic to leishmaniasis, Ahmed et al. [36] showed that essential oils obtained from Thymus hirtus is significantly active against both Leishmania major and L. infantum, while that of Ruta chalepensis was only active against L. infantum. The difference in the effectiveness of these oils against different species of Leishmania can possibly be attributed to their distinct chemical composition.

The ability of L. camara essential oil to inhibit the epimastigote form of Trypasomia cruzi was evaluated for the first time. The results demonstrated that L. camara essential oil at relatively high concentration $(250 \mu \mathrm{g} / \mathrm{mL})$ exhibited $67.39 \%$ inhibition against T. cruzi. On the other hand, $500 \mu \mathrm{g} / \mathrm{mL}$ of L. camara essential oil was highly toxic to NCTC929 fibroblast. The toxicity of essential oil from L. camara was possibly related to its triterpenes (i.e., lantadenes) reported to be present in all parts of the plant [37]. However, compounds other than triterpenes may be involved in L. camara essential oil toxicity. In line of this, Martínez-Díaz et al. [38] demonstrated recently that (E)-caryophyllene, which was the major component of L. camara essential oil, exhibits potent antiparasitic effect against T. cruzi. This result suggests that $(E)$-caryophyllene might be at least in part, responsible for the observed anti-parasitic activity. However, we cannot rule out the fact that minor and major compounds from L. camara essential oil should have made significant contribution to the oil's activity.

Recently, Charneau et al. [39] screened Brazilian Cerrado plant extracts for their anti-protozoan activity. They demonstrated that eight extracts from Connarus suberosus, Blepharocalyx salicifolius, Psidium laruotteanum, and Myrsine guianensis exhibited high anti-protozoan activity with $\mathrm{IC}_{50}$ values lower than $10 \mu \mathrm{g} / \mathrm{mL}$. Similarly, Costa et al. [40] showed that essential oils obtained from the leaves of species of Annonaceae family, specifically, Annona pickelli and A. salzmannii, have potent trypanocidal activity against Trypanosoma cruzi with $\mathrm{IC}_{50}$ value lower than $100 \mu \mathrm{g} / \mathrm{mL}$. If we compare our results with that obtained by Charneau et al. [39] and Costa et al. [40] under a similar assay system, we can presume that the anti-Trypanosoma cruzi activity of L. camara leaf essential oil was relatively low $\left(\mathrm{IC}_{50}=201.94 \mu \mathrm{g} / \mathrm{mL}\right)$.

\section{Materials and Methods}

\subsection{Chemicals}

Resazurin sodium salt was obtained from Sigma (St. Louis, MO, USA) and stored at $4{ }^{\circ} \mathrm{C}$ and protected from light. A solution of resazurin was prepared in 1\% phosphate buffer, $\mathrm{pH} 7$, and filter sterilized prior to use. Chlorophenol red- $\beta$-D-galactopyranoside (CPRG; Roche, Indianapolis, IN, USA) was dissolved in 0.9\% Triton X-100 (pH 7.4). Penicillin G (Ern, S.A., Barcelona, Spain), streptomycin (Reig Jofré S.A., Barcelona, Spain), and dimethylsulfate were also used. 


\subsection{Plant Material and Isolation of Essential Oil}

The leaves of Lantana camara were collected in Padre Cicero, Crato-Ceara $\left(7^{\circ} 22^{\prime} \mathrm{S} ; 3^{\circ} 28^{\prime} \mathrm{W}, 492 \mathrm{~m}\right.$ above sea level), Brazil, in June 2012. The plant material was identified and the specimen was deposited in the Herbarium Caririense Dárdano de Andrade-Lima, Regional University of Cariri (URCA), under the number 7518 .

The essential oil from the dried leaves of L. camara was obtained by hydro-distillation using a Clevenger-type apparatus as described by Guenther [41] with small modifications. At the end of the extraction process, the oil was dried over anhydrous sodium sulfate to remove the aqueous phase, and then stored at $4{ }^{\circ} \mathrm{C}$ prior to use.

\subsection{Gas Chromatography Coupled with Mass Spectrometry (GC/MS) Analysis}

The essential oil after preparation was submitted to GC/MS analysis in a Varian 3800 Gas Chromatograph (SHIMADZU, Houston, TX., USA) equipped with a fused silica capillary column $(25 \mathrm{~m} \times 0.25 \mathrm{~mm}$ i.d., film thickness $0.25 \mu \mathrm{m}$ ) coated with SE-54; carrier gas helium, flow rate $1.0 \mathrm{~mL} / \mathrm{min}$ and with split mode. The injector temperature and detector temperature were $200{ }^{\circ} \mathrm{C}$ and $250{ }^{\circ} \mathrm{C}$, respectively. The column temperature was programmed from $50^{\circ} \mathrm{C}$ to $300^{\circ} \mathrm{C}$ at $4{ }^{\circ} \mathrm{C} / \mathrm{min}$. Individual components were identified by matching their $70 \mathrm{eV}$ mass spectra with those of the spectrometer database using the Wiley L-built library and two other computer libraries' MS searches using retention indices as a pre-selection routine, as well as by visual comparison of the fragmentation pattern with those reported in the literature [32]. The percentage composition was obtained from electronic integration measurements using flame ionization detection (FID), also set at $250{ }^{\circ} \mathrm{C}$. n-Alkanes $\left(\mathrm{C}_{7}-\mathrm{C}_{30}\right)$ were used as reference points in the calculation of relative retention indices (RIs). The concentration of the identified compounds was computed from the GC peak area without any correction factor. GC analyses were equipped with a flame ionization detector (FID) and a J and W Scientific DB-5 fused silica capillary column $(30 \mathrm{~m} \times 0.25 \mathrm{~mm} \times 0.25 \mu \mathrm{m})$. Injector and detector temperatures were $250{ }^{\circ} \mathrm{C}$ and $290^{\circ} \mathrm{C}$, respectively. Hydrogen was used as carrier gas, flow rate $1.0 \mathrm{~mL} / \mathrm{min}$, split mode (1:10).

\subsection{Cell Lines Used}

For in vitro studies of T. cruzi, the clone CL-B5 was used [42]. Parasites were stably transfected with the Escherichia coli $\beta$-galactosidase gene (lacZ), provided by Buckner F. at the Instituto Conmemorativo Gorgas (Panama, Brazil). Epimastigotes were grown at $28^{\circ} \mathrm{C}$ in liver infusion tryptose broth (Difco, Detroit, MI, USA) with 10\% fetal bovine serum (FBS) (Gibco, Carlsbad, CA, USA), penicillin (Ern, S.A., Barcelona, Spain), and streptomycin (Reig Jofré S.A., Barcelona, Spain), as described previously [43], and harvested during the exponential growth phase.

Culture of L. braziliensis was obtained from the Instituto de Investigaciones en Ciencias de la Salud, Asunción, Paraguay-IICS. The maintenance of the strain, the form of cultivation, and isolation of shape promastigota were performed following the procedures described by Roldós et al. [43]. The inhibition assays of promastigotes was performed using the strain of L. braziliensis (MHOM/BR/75/M2903), grown at $22{ }^{\circ} \mathrm{C}$ in Schneider's Drosophila medium supplemented with $20 \%$ FBS.

For the cytotoxicity assays, the fibroblast cell line NCTC929 grown in Minimal Essential Medium (Sigma) was used. The culture medium was supplemented with heat-inactivated FBS (10\%), penicillin $\mathrm{G}(100 \mathrm{U} / \mathrm{mL})$, and streptomycin $(100 \mu \mathrm{g} / \mathrm{mL})$. Cultures were maintained at $37^{\circ} \mathrm{C}$ in humid atmosphere with $5 \% \mathrm{CO}_{2}$. The viability of these strains was assessed according to Roldós et al. [43], through the use of resazurin as a colorimetric method.

\subsection{Trypanocidal Assay}

The essential oil from the leaves of L. camara was evaluated against epimastigotes forms of T. cruzi using cultures that have not reached the stationary phase [44]. Briefly, epimastigotes were seeded at $1 \times 10^{5} / \mathrm{mL}$ in $200 \mu \mathrm{L}$ of liver tryptose broth medium. The plates were then incubated with or without 
different concentrations of L. camara essential oil $(250,125$, and $62.5 \mu \mathrm{g} / \mathrm{mL})$ at $28^{\circ} \mathrm{C}$ for $72 \mathrm{~h}$, at which time $50 \mu \mathrm{L}$ of CPRG solution $(200 \mu \mathrm{M})$ was added. The plates were incubated at $37^{\circ} \mathrm{C}$ for an additional $6 \mathrm{~h}$ and were then read at $595 \mathrm{~nm}$. Nifurtimox $(100,50,10,1,0.5$, and $0.1 \mu \mathrm{g} / \mathrm{mL})$ was used as reference standard. The efficacy of the essential oil was estimated by calculating the anti-epimastigotes percentage $(\mathrm{AE} \%)$ as follow: $\% \mathrm{AE}=\left[\left(\mathrm{A}_{\mathrm{exp}}-\mathrm{A}_{\text {boil }}\right) /\left(\mathrm{A}_{\text {cont }}-\mathrm{A}_{\text {cult }}\right)\right] \times 100$, where, $\mathrm{A}_{\mathrm{exp}}=$ absorbance of the experimental sample; $\mathrm{A}_{\text {boil }}=$ Absorbance of the blank sample; $\mathrm{A}_{\text {cont }}=$ Absorbance of the control; $\mathrm{A}_{\text {cult }}=$ Absorbance of the culture medium. It should be stressed that the essential oil was solubilized in dimethyl sulfoxide (DMSO) prior to the experiment.

\subsection{Leishmanicidal Assay}

Cultures of promastigotes of Leishmania braziliensis were grown in 96-well microplates to a concentration of $10^{6}$ cells $/ \mathrm{mL}$. Different concentrations of L. camara essential oil (250, 125, 100, $80,70,62.5$, and $50 \mu \mathrm{g} / \mathrm{mL}$ ) previously dissolved in DMSO, was incubated with the parasite for $72 \mathrm{~h}$ at $28{ }^{\circ} \mathrm{C}$. The concentration of DMSO in the wells was not higher than $0.01 \%$. The concentrations of the oil were obtained by serial dilutions. At the end of the incubation period, $20 \mu \mathrm{L}$ of resazurin $(2 \mathrm{mM})$ was added to the plates and the efficacy of the essential oil or the standard drug was evaluated by direct counting of cells. Each test was performed in triplicate. Pentamidine (100, 50, 25, 12.5, 6.25, and $3.125 \mu \mathrm{g} / \mathrm{mL}$ ) was used as standard drugs. The results were expressed in percent inhibition of promastigotes (\%AP) and compared with untreated control.

\subsection{Cytotoxicity Assay}

NCTC929 fibroblasts were plated in 96-well microplates at a final concentration of $5 \times 10^{4}$ cells / well. The cells were grown at $37^{\circ} \mathrm{C}$ in an atmosphere of $5 \% \mathrm{CO}_{2}$. After that, the culture medium was removed and L. camara essential oil at different concentrations $(500,250$, and $125 \mu \mathrm{g} / \mathrm{mL}$ ) and a new culture was performed for $24 \mathrm{~h}$. Then, $20 \mu \mathrm{L}$ of $2 \mathrm{mM}$ resazurin was added to each well. The plates were incubated for $3 \mathrm{~h}$, and the reduction of resazurin was measured using dual absorbance at wavelengths of 490 and $595 \mathrm{~nm}$. The value of the control (blank) was subtracted. Nifurtimox at concentrations of 600, 400, 200, 100,50 , and $25 \mu \mathrm{g} / \mathrm{mL}$ was used as reference.

\subsection{Statistical Analysis}

Results are expressed as mean \pm standard error of mean (SEM) of at least three independent experiments performed in triplicate.

\section{Conclusion}

This study demonstrates for the first time the anti-parasitic effect of L. camara essential oil against L. braziliensis and T. cruzi. However, the oil was also toxic to fibroblasts, indicating its potential toxicity to mammalian cells. Consequently, further studies with isolated compounds from L. camara essential oil need to be investigated to elucidate the mechanism(s) underlying its anti-parasitic action.

Acknowledgments: Luiz Marivando Barros is particularly grateful to CAPES, CAPES/DINTER/URCA-UFSM. The authors would like to thank the professors from NAPO (Center for Analysis and Organic Research at UFSM) for providing the GC/MS chromatograms and spectra and Ademir Farias Morel (Department of Chemistry at UFSM) for the assessment of the $n$-alkane series. Jean Paul Kamdem is particularly grateful to CAPES, TWAS-CNPq and CNPq for the financial support.

Author Contributions: João Batista Teixeira Rocha and Jean Paul Kamdem designed the research; Henrique Douglas Melo Coutinho and Irwin Rose Alencar de Menezes provided the space and the reagents; Luiz Marivando Barros, Antonia Eliene Duarte, Maria Flaviane Bezerra Morais-Braga, Celeste Vega, Nadghia Figueiredo Leite and Emily Pansera Waczuk performed the experiments and contributed to data collection; Luiz Marivando Barros and Jean Paul Kamdem wrote the manuscript. João Batista Teixeira Rocha contributed to the revision of the manuscript. All authors have read and approved the final version of the manuscript.

Conflicts of Interest: The authors declare no conflict of interest. 


\section{References}

1. WHO-World Health Organization. Leishmaniasis Magnitude of the Problem, 2010. Available online: http://www.who.int/ leishmaniasis/burden/magnitude/burden_magnitude/en/print.html (assessed on 1 October 2015).

2. Shaw, J.J. Taxonomy of the genus Leishmania: Present and future trends and their implications. Mem. Inst. Oswaldo Cruz 1994, 89, 471-478. [CrossRef] [PubMed]

3. Desjeux, P. Leishmaniasis: Public health aspects and control. Clin. Dermatol. 1996, 14, 417-423. [CrossRef]

4. Ashford, R.W. The leishmaniases as model zoonoses. Ann. Trop. Med. Parasitol. 1997, 91, 693-701. [CrossRef] [PubMed]

5. Herwaldt, B.L. Leishmaniasis. Lancet 1999, 354, 1191-1199. [CrossRef]

6. Croft, S.L.; Sundar, S.; Fairlamb, A.H. Drug resistance in Leishmaniasis. Clin. Microbiol. Rev. 2006, 19, 111-126. [CrossRef] [PubMed]

7. Cruz, A.K.; de Toledo, J.S.; Falade, M.; Terrao, M.C.; Kamchonwongpaisan, S.; Kyle, D.E.; Uthaipibull, C. Current treatment and drug discovery against Leishmania spp. and Plasmodium spp.: A review. Curr. Drug Targets 2009, 10, 178-192. [CrossRef]

8. WHO-World Health Organization. Neglected Tropical Diseases-Innovative and Intensified Disease Management; World Health Organization: Geneva, Switzerland, 2007.

9. Mishra, B.B.; Singh, R.K.; Srivastava, A.; Tripathi, V.J.; Tiwari, V.K. Fighting against leishmaniasis: Search of alkaloids as future true potential anti-leishmanial agents. Mini-Rev. Med. Chem. 2009, 9, 107-123. [CrossRef] [PubMed]

10. Croft, S.L.; Coombs, G.H. Leishmaniasis-current chemotherapy and recent advances in the search for novel drugs. Trends Parasitol. 2003, 19, 502-508. [CrossRef] [PubMed]

11. Natera, S.; Machuca, C.; Padrón-Nieves, M.; Romero, A.; Diaz, E.; Ponte-Sucre, A. Leishmania spp.: Proficiency of drug-resistant parasites. Int. J. Antimicrob. Agents 2007, 29, 637-642. [CrossRef] [PubMed]

12. Clem, A.A. Current perspective on Leishmaniasis. J. Glob. Infect. Dis. 2010, 2, 124-126. [CrossRef] [PubMed]

13. Rassi, A., Jr.; Rassi, A.; Marin-Neto, J.A.M. Chagas disease. Lancet 2010, 375, 1388-1402. [CrossRef]

14. Mougabure-Cueto, G.; Picollo, M.I. Insecticide resistance in vector Chagas disease: Evolution, mechanisms and management. Acta Trop. 2015, 149, 70-85. [CrossRef] [PubMed]

15. Coura, J.R.; de Castro, S.L. A critical review on Chagas disease chemotherapy. Mem. Inst. Oswaldo Cruz 2002, 97, 3-24. [CrossRef]

16. Soeiro, M.N.; de Castro, S.L. Trypanosoma cruzi targets for new chemotherapeutic approaches. Expert Opin. Ther. Targets 2009, 13, 105-121. [CrossRef] [PubMed]

17. Rocha, L.G.; Almeida, J.R.G.S.; Macêdo, R.O.; Barbosa-Filho, J.M. A review of natural products with antileishmanial activity. Phytomedicine 2005, 12, 514-535. [CrossRef] [PubMed]

18. Ndjonka, D.; Rapado, L.N.; Silber, A.M.; Liebau, E.; Wrenger, C. Natural products as a source for treatting negleted parasitic diseases. Int. J. Mol. Sci. 2013, 14, 3395-3439. [CrossRef] [PubMed]

19. Derda, M.; Hadas, E. The use of phytotherapy in diseases caused by parasitic protozoa. Acta Parasitol. 2014, 60, 1-8. [CrossRef] [PubMed]

20. Sharma, O.P.; Makkar, H.P.; Dawra, R.K. A review of the noxious plant Lantana camara. Toxicon 1988, 26, 975-987. [CrossRef]

21. Ghisalberti, E.L. Lantana camara Linn (Review). Fitoterapia 2000, 71, 467-485. [CrossRef]

22. Day, M.D.; Wiley, C.J.; Playford, J.; Zalucki, M.P. Lantana: Current Management Status and Future Prospects; ACIAR Monograph 102; Australian Centre for International Agricultural Research: Canberra, Australia, 2003.

23. Kalita, S.; Kumar, G.; Karthik, L.; Rao, K.V.B. A review on medicinal properties of Lantana camara. Res. J. Pharm. Technol. 2012, 5, 771-775.

24. Bhagwat, S.A.; Breman, E.; Thekaekara, T.; Thornton, T.F.; Willis, K.J. A battle lost? Report on two centuries of invasion and management of Lantana camara L. in Australia, India and South Africa. PLoS ONE 2012, 7, e32407. [CrossRef] [PubMed]

25. Sharma, O.P.; Makkar, H.P.; Dawra, R.K.; Negi, S.S. A review of the toxicity of Lantana camara (Linn) in animals. Clin. Toxicol. 1981, 18, 1077-1094. [CrossRef] [PubMed]

26. Tripathi, A.K.; Shukla, B.N. Antifungal activity of some plant extracts against Fusarium oxysporum sp. causing wilt of linseed. J. Mycol. Plant Pathol. 2002, 32, 266-267.

27. Braga, F.G.; Bouzada, M.L.M.; Fabri, R.L.; Matos, M.O.; Moreira, F.O.; Scio, E.; Coimbra, E.S. Antileishmanial and antifungal activity of plants used in traditional medicine in Brazil. J. Ethnopharmacol. 2007, 111, 396-402. [CrossRef] [PubMed] 
28. Deena, M.J.; Thoppil, J.E. Antimicrobial activity of the essential oil of Lantana camara. Fitoterapia 2000, 71, 453-455. [CrossRef]

29. Begum, S.; Wahab, A.; Siddiqui, B.S. Pentacyclic tri-terpenoids from the aerial parts of Lantana camara. Chem. Pharm. Bull. 2003, 51, 134-137. [CrossRef] [PubMed]

30. Kumar, V.P.; Chauhan, N.S.; Padh, H.; Rajani, M. Search for antibacterial and antifungal agents from selected Indian medicinal plants. J. Ethnopharmacol. 2006, 107, 182-188. [CrossRef] [PubMed]

31. Seth, R.; Mohan, M.; Singh, P.; Haider, S.Z.; Gupta, S.; Bajpai, I.; Singh, D.; Dobhal, R. Chemical composition and antibacterial properties of the essential oil and extracts of Lantana camara Linn. from Uttarakhand (India). Asian Pac. J. Trop. Biomed. 2012, 2, S1407-S1411. [CrossRef]

32. Adams, R.P. Identification of Essential Oil Components by Gas Chromatography/Mass Spectroscopy; Allured Publishing Corporation: Carol Stream, IL, USA, 1995; p. 456.

33. Ibrahim, M.A.; Mohammed, A.; Isah, M.B.; Aliyu, A.B. Anti-trypanosomal activity of African medicinal plants: A review update. J. Ethnopharmacol. 2014, 154, 26-54. [CrossRef] [PubMed]

34. Machado, R.R.P.; Júnior, W.V.; Lesche, B.; Coimbra, E.S.; de Souza, N.B.; Abramo, C.; Soares, G.L.G.; Kaplan, M.A.C. Essential oil from leaves of Lantana camara: A potential source of medicine against leishmaniasis. Braz. J. Pharmacogn. 2012, 22, 1011-1017. [CrossRef]

35. Morais-Teixeira, E.; Carvalho, A.S.; Costa, J.C.S.; Duarte, S.L.; Mendonça, J.S.; Boechat, N.; Rabello, A. In vitro and in vivo activity of meglumine antimoniate produced at Farmanguinhos-Fiocruz, Brazil, against Leishmania (Leishmania) amazonensis, L (L.) chagasi and L (Viannia) braziliensis. Mem. Inst. Oswaldo Cruz. 2008, 103, 358-362. [CrossRef] [PubMed]

36. Ahmed, S.B.; Sghaier, R.M.; Guesmi, F.; Kaabi, B.; Mejri, M.; Attia, H.; Laouini, D.; Smaal, I. Evaluation of antileishmanial, cytotoxic and antioxidant activities of essential oils extracted from plants issued from leishmaniasis-endemic region of Sned (Tunisia). Nat. Prod. Res. 2011, 25, 1195-1201. [CrossRef] [PubMed]

37. Sharma, O.P.; Sharma, S.; Pattabhi Pattabhi, V.; Mahato, S.B.; Sharma, P.D. A review of the hepatotoxic plant Lantana camara. Crit. Rev. Toxicol. 2007, 37, 313-352. [CrossRef] [PubMed]

38. Martínez-Díaz, R.A.; Ibánez-Escribano, A.; Burillo, J.; de la Heras, L.; del Prado, G.; Agulló-Ortuno, M.T.; Julio, L.F.; Gonzáles-Coloma, A. Thrypanocidal, trichomonacidal and cytotoxic components of cultivated Artemisia absinthium Linnaeus (Asteraceae) essential oil. Mem. Inst. Oswaldo Cruz. 2015, 110, 693-699. [CrossRef] [PubMed]

39. Charneau, S.; de Mesquita, M.L.; Bastos, I.M.; Santana, J.M.; de Paula, J.E.; Grellier, P.; Espindola, L.S. In vitro investigation of Brazilian Cerrado plant extract activity against Plasmodium falciparum, Trypanosoma cruzi and T. brucei gambiense. Nat. Prod. Res. 2015, 29, 1-7. [CrossRef] [PubMed]

40. Costa, E.V.; Dutra, L.M.; Salvador, M.J.; Ribeiro, L.H.; Gadelha, F.R.; de Carvalho, J.E. Chemical composition of the essential oils of Annona pickelii and Annona salzmannii (Annonaceae), and their antitumor and trypanocidal activities. Nat. Prod. Res. 2013, 27, 997-1001. [CrossRef] [PubMed]

41. Guenther, E. Individual Essential Oils of the Plant Families Rutaceae and Labiatae; Robert, E., Ed.; Krieger Publishing Company, Inc.: New York, NY, USA, 1975; Volume 3, pp. 316-319.

42. Le Senne, A.; Muelas-Serrano, S.; Fernandez-Portillo, C.; Escario, J.A.; Gómez-Barrio, A. Biological characterization of a beta-galactosidase expressing clone of Trypanosoma cruzi CL strain. Mem. Inst. Oswaldo Cruz 2002, 97, 1101-1105. [CrossRef] [PubMed]

43. Roldós, V.; Nakayama, H.; Rolón, M.; Montero-Torres, A.; Trucco, F.; Torres, S.; Vega, C.; Marrero-Ponce, Y.; Heguaburu, V.; Yaluff, G.; et al. Activity of a hydroxybibenzyl bryophyte constituent against Leishmania spp. and Trypanosoma cruzi: In silico, in vitro and in vivo activity studies. Eur. J. Med. Chem. 2008, 43, 1797-1807. [CrossRef] [PubMed]

44. Vega, C.; Rólon, M.; Martínez-Fernández, A.R.; Escario, J.A.; Gómez-Barrio, A. A new pharmacological screening assay with Trypanosoma cruzi epimastigotes expressing $\beta$-galactosidase. Parasitol. Res. 2005, 95, 296-298. [CrossRef] [PubMed]

Sample Availability: Samples of the compounds are not available from the authors.

(C) 2016 by the authors; licensee MDPI, Basel, Switzerland. This article is an open access article distributed under the terms and conditions of the Creative Commons by Attribution (CC-BY) license (http:/ / creativecommons.org/licenses/by/4.0/). 